\title{
Transition to first birth during the Great Recession: the case of Greece
}

\author{
Charalampos Dantis and Ester Lucia Rizzi (D)
}

\author{
* Correspondence: ester.rizzi@ \\ uclouvain.be \\ Center for Demographic Research \\ (DEMO), Université Catholique de \\ Louvain, Place Montesquieu, 1 / \\ L2.08.03, 1348 Louvain-la-Neuve, \\ Belgium
}

\begin{abstract}
In this study, we examine the effects of the economic uncertainty of partners on the transition to first birth in Greece before and after the onset of the recent economic crisis. After selecting a sample of childless couples, we applied a random effects model to EU-SILC data for the period 2005-2013. Few studies have focused on the association between economic uncertainty and fertility in Greece considering characteristics of both partners. Even fewer studies have examined panel data in the context of the recent crisis. Our findings show that Greek couples in which both partners are employed, have a high income, or are highly educated are in a more favourable position to have a first child. During the Greek Great Recession, corresponding in our study to the period 2010-2013, the odds of having a first child decreased to half the odds in the 2005-2009 period. The recession period also modified the effect of couples' characteristics on first childbearing. During the economic crisis, male breadwinner couples were particularly penalized in their transition to have a first child. Surprisingly, couples with at least one temporary worker, usually the woman, were encouraged to have their first child. Implications in terms of gender and social inequality are discussed in the concluding section, and selection processes at play are also discussed.
\end{abstract}

Keywords: Fertility, Economic uncertainty, Economic recession, Greece

\section{Introduction}

Since the 1960s, developed countries have been characterized by a decline in fertility. This process has been associated with an ideational change, defined as the second demographic transition and characterized by a process of secularization and a greater emphasis on individual self-realization (Lesthaeghe, 2010). Starting in the 1960s, we have also observed a massive entrance of women in the labour market that is negatively correlated with fertility (Engelhardt et al., 2004; Engelhardt, Prskawetz, 2004; Kögel, 2004). In addition, modern societies are characterized by a process of globalization that has contributed to the deterioration of the socio-economic situation of young adults and that has delayed family formation (Comolli, 2017; Aasve et al., 2013; Buchholz et al. 2009; McDonald 2006).

In the general framework of low fertility and societal changes, Southern European countries present specific features. First, Southern European countries exhibit the highest rates of youth unemployment. In Southern Europe, uncertainty might be particularly strong because the dominant form of the welfare state is a familistic one characterized by poor institutional support for vulnerable social groups (the unemployed, youth, etc.) that must rely on family support (Barbieri and Bozzon, 2016; Aassve et al., 2006). The consequences are a considerable increase in poverty risk for young adults, late departure from the parental home, late entry

(c) The Author(s). 2020 Open Access This article is distributed under the terms of the Creative Commons Attribution 4.0 International License (http://creativecommons.org/licenses/by/4.0/), which permits unrestricted use, distribution, and reproduction in any medium, provided you give appropriate credit to the original author(s) and the source, provide a link to the Creative Commons license, and indicate if changes were made. 
into the labour market, and low fertility (Barbieri and Bozzon, 2016; Balbo et al. 2013; Goldstein et al., 2009a, b; Billari, 2008; Mills and Blossfeld, 2005; Dalla Zuanna and Micheli, 2004; Kohler et al. 2002; Dalla Zuanna, 2001). Second, since the 1980s, the negative link between female labour force participation and fertility has been weakened in non-Southern European countries. However, this negative association remains strong in Southern European countries (Kögel, 2004), pointing to limitations in family-friendly policies.

In the 2000s, fertility was slightly increasing in developed countries as an effect of the partial recovery of the fertility choices of generations that had previously postponed having a child (Sobotka, 2011; Goldstein et al., 2009a, b; Bongaarts \& Feeney 1998). This effect was also observable in Southern European countries (Caltabiano et al., 2009). However, the 2008 Great Recession halted this trend.

In this study, we focus on Greece. Our first aim is to demonstrate the association between the economic uncertainty of partners and first birth. Since economic uncertainty concerns mostly young people in Southern Europe, we focus on the first stages of family formation and consider the transition to first birth. In line with previous findings, we consider how first birth is affected by occupational status, type of contract, income, and education (Fahlén and Olàh, 2018; Vignoli et al., 2012; Santarelli, 2011; Kreyenfeld, 2010). Our perspective on couples, jointly considering characteristics of both partners, has rarely been applied in the previous literature.

The second aim of this study is to ascertain the effect of the Great Recession on first birth. Previous studies have shown that economic recessions particularly affect younger cohorts and first birth (Golaz et al. 2018; Comolli, 2017; Goldstein et al. 2013; Neels et al. 2013; Adsera, 2011). However, few studies have focused on how the relationship between couples' economic uncertainty and first birth has changed as a result of the recent economic recession (Kotzamanis, 2018; Tragaki and Bagavos, 2014). To our knowledge, no studies on Greece have addressed this issue by conducting multivariate and longitudinal analyses or by considering multiple indicators of economic uncertainty for both partners.

Our analysis is based on longitudinal data from the EU-SILC survey (EU Statistics on Income and Living Conditions) for Greece. We select a sub-sample of childless couples and consider survey waves from 2005 to 2013, a period overlapping with the current economic crisis.

In the EU-SILC data, information about the level of income, education, occupational status, and type of contract (permanent or not) is available for both partners. In our sample, which includes only couples, most men (92\%) are employed and have permanent contracts, which is already notable and indicates that for men, being employed and having a permanent contract might be preconditions for entering into a union.

Our study is structured as follows. After describing the Greek context in the "The Greek context" section, we present the theoretical and empirical background in the "Theoretical background" section, together with our hypotheses. We consider the previous literature on how men's and women's economic uncertainty affects first birth. We also examine economic uncertainty as an aggregate phenomenon and focus on previous studies of economic recession and fertility. In the "Data and methods" section, we present our data, the operationalization of concepts, and the methods that account for the panel structure of the data. In the "Results" section, we present our results. Finally, in the "Discussion and conclusions" section, we interpret the results and note the limitations of our study.

It may be useful here to anticipate the main limitations of our study. Since we studied couples, our study did not include people who were unable to leave their parental homes because of their economic uncertainty. Moreover, we compared transition to 
first birth before the crisis (2005-2009) and during the crisis (2010-2013), but because of the sample size, we were unable to consider each individual year.

\section{The Greek context}

In Greece, from the mid-1990s to 2003, the total fertility rate (TFR) was less than 1.3 children per woman (Eurostat database accessed in August 2018). As in other Southern European countries, the postponement of marriage and fertility has been observed, while new forms of unions and births out of wedlock remain exceptions (Gavalas et al. 2014). In 2013, Greece was the only European country in which the percentage of births out of wedlock was still less than $10 \%$ (Eurostat database accessed in July 2019). Beginning in 2004, the increase in fertility ushered in a new trend. Greece's TFR increased from 1.3 children per woman in 2004 to 1.5 in 2008 (Eurostat database accessed in March 2019). This trend was interrupted by the recent economic crisis: the number of births decreased by $15.2 \%$ (Vrachnis et al. 2014), and the TFR decreased to 1.3 in 2013 (Eurostat database accessed in July 2019). In a recent study, Salvati (2018) showed that during the recession, economic conditions worsened in all Greek districts and led to a decline in the growth rate of the population, except in certain coastal and tourist districts.

In addition to low fertility, another feature that Greece has in common with other Southern European countries is youth and female labour precariousness. In 2008, youth unemployment (15- to 24-year-olds) was already double the national average, reaching 28.3\% (Kretsos, 2014; Eurostat database accessed in August 2018). In the same year, female unemployment was decreasing but still high compared to that in other European countries (11.5\% in 2008, Eurostat database accessed in August 2018). The economic crisis exacerbated this situation. The youth (15- to 24year-olds) unemployment rate reached 58.3\% in 2013 (Eurostat database accessed in July 2019).

Regarding female employment, Greek experienced a greater decline than other Southern countries, with an employment rate reaching $40 \%$ in 2013. A dramatic decline was also observed for Greek men, with an employment rate of 49\% in 2013 (Figs. 1 and 2).

As an effect of the crisis, dual-earner households with children decreased by $9 \%$ between 2008q2 and 2012q2, from 55.1 to 46\%. The percentage of households with children in which the man is the provider and the woman is inactive in the labour market decreased by $10 \%$ in the same period, from 34 to $24 \%$ (Karamessini, 2014). Meanwhile, the share of male breadwinner households with unemployed women increased by $6 \%$, and the share of female breadwinner households increased by 5\% (Karamessini, 2014).

Austerity measures have contributed further to worsening the economic conditions of young people (Kretsos, 2014). These policies have resulted in reductions in public expenditures and in the social security system. Moreover, firing costs were reduced, together with unemployment benefits for seasonal workers. A special employment regime for young people was also implemented in 2009, with a reduction in the minimum wage for workers younger than 25 years old (Kretsos, 2014). In addition, if the economic crisis deprived young Greek adults of their salaries, according to Matsaganis (2011), the crisis also deprived them of their parents' pensions. Already by 2008, the government had introduced a series of austerity measures with changes in the pension system that reinforced the links between contributions and pensions and increased the age of retirement (Papadopoulos and Roumbakis, 2013). Moreover, a 6\% pension reduction penalty for each year of early retirement was introduced into the pension calculation (Papadopoulos Roumbakis, 2013). Given the high percentage of young adults living with their parents in Greece (Albertini et al. 2007), such measures were 


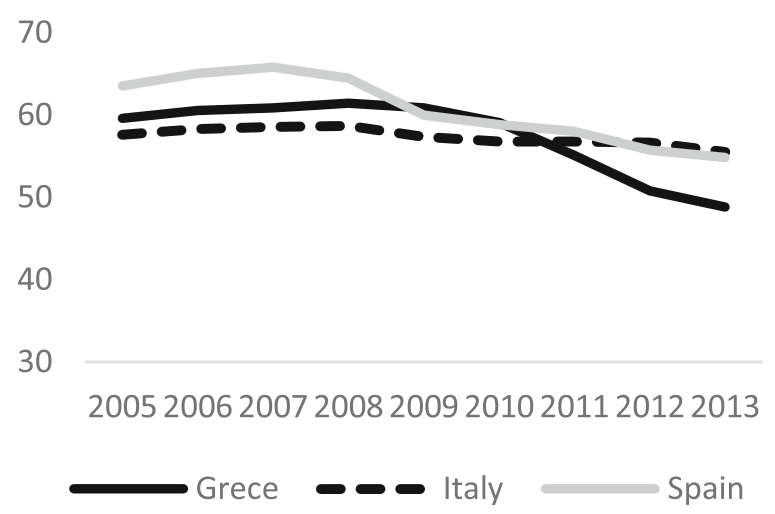

Fig. 1 Male employment rate, 2005-2013. Source: OECD (2019), Employment rate (indicator). doi: 10.1787/ 1 de68agb-en (Accessed 26 February 2019)

not without influence and might have contributed, between 2009 and 2010, to the increase in poverty rates by $12.6 \%$ among the unemployed (Tzanatos and Monogios, 2013).

Public spending on families in Greece, among the lowest in Europe before the crisis, was also affected. In 2009, family benefits in cash stopped increasing, and in 2010, public spending on services for families, amounting to approximately $0.43 \%$ of the GDP, started decreasing (OCDE, Family database accessed in February 2019).

Researchers enquiring into the consequences of the economic crisis in Greece have typically identified 2008 as the beginning of the crisis (Tragaki and Bagavos, 2014; Vaughan-Whitehead, 2013; Papadopoulos and Roumbakis, 2013). In this year, unemployment started increasing (Goldstein et al. 2013), and the first austerity measures emerged. Studies taking 2009 as the starting point of the crisis have been less frequent (Tzanatos and Monogios, 2013). Fertility time series for Greece were increasing before 2008, stabilized in 2008 and 2009, and then started decreasing (Goldstein et al. 2013). To capture the negative trend, in our study, we refer to 2010 as a critical year.

\section{Economic uncertainty and first birth}

At the individual level, economic uncertainty is usually defined with reference to unemployment, job instability, and low income (Oppenheimer 1988; Kreyenfeld et al. 2012). Over the last

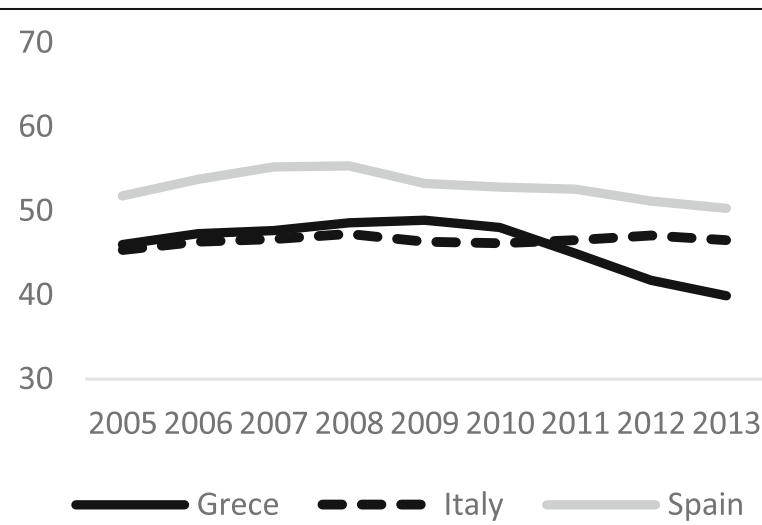

Fig. 2 Female employment rate, 2005-2013. Source: OECD (2019), Employment rate (indicator). doi: 10.1787/1de68a9b-en (Accessed 26 February 2019) 
two decades, the process of globalization has caused economic deregulation that has primarily affected young adults and increased their economic uncertainty (Comolli, 2017; Aasve et al., 2013; Buchholz et al. 2009; McDonald, 2006). Economic uncertainty does not affect states or regions in the same way, but it is related to "institutional filters" (Mills and Blossfeld, 2005).

In this study of the effects of economic uncertainty on fertility, we focus on first birth. As stated in the "Introduction" section, economic uncertainty particularly affects young adults who might choose to postpone parenthood to obtain a more stable position in the labour market (Fahlén and Olàh, 2018; Vignoli et al., 2012; Santarelli, 2011; Kreyenfeld, 2010).

The relationship between economic uncertainty and fertility can differ between men and women. Using several indicators of economic uncertainty in developed countries, Blossfeld et al. (2005) found a negative relation between economic uncertainty among men and first birth, while more contradictory results were found for women. However, studies considering the joint effects of both partners' characteristics remain rare. Accounting for a joint effect of partners' economic uncertainty on first birth means acknowledging the process of negotiation, accumulation, or compensation for partners' resources. In this process, traditional or egalitarian norms concerning gender-based economic roles can play a role.

In addition to the individual level, economic uncertainty "may also be conceptualized as an aggregate phenomenon, reflecting general uncertainties felt by all people during, for example, an economic recession" (Sobotka et al. 2011). It has been shown that economic recessions and adverse economic contexts affect younger cohorts and first birth (Golaz et al. 2018; Comolli, 2017; Goldstein et al. 2013; Neels et al. 2013; Adsera, 2011). In this study, our assumption is that the association between economic uncertainty and first birth changed with the Great Recession.

In the next section, we present theoretical insights and empirical results from previous studies on the relation between first birth and economic uncertainty. We place special emphasis on the joint effects of partners' characteristics on first birth and on studies referring to Southern Europe. We also present the theoretical reasoning and some previous empirical evidence concerning how the Great Recession changed the relation between economic uncertainty and first birth.

\section{Theoretical background}

\section{Partner incomes and first birth}

In its initial formulation, Becker's economic theory maintained a positive relation between men's income and number of children and posited that for women, factors other than income determine fertility (such as knowledge of contraception or living in rural/ urban areas, Becker, 1960). Later, he emphasized the quantity-quality trade-off (Becker and Lewis 1973). In particular, a higher income is associated with greater investment in the "quality of children" and thus negatively correlated with the quantity of children. For the first child, however, we could assume the absence of the quality-quantity tradeoff, and we could expect a positive relationship between men's income and fertility.

In accordance with Becker's view, Oppenheimer (1988) emphasized the importance of men's earnings and socio-economic characteristics in family formation. According to the work of Oppenheimer (1988), age at marriage increases when men have more difficulty establishing their careers. This phenomenon has been called the "uncertainty hypothesis". Although Oppenheimer's theoretical model was applied to marriage, it also reasonably applies to first birth. According to Oppenheimer (1988), even in periods when female labour 
force participation becomes increasingly important, men's economic stability remains important (Oppenheimer, 1994; Oppenheimer, 1988). This trend is especially true in contexts with stronger specialization of roles in the family (Oppenheimer, 1988). In accordance with these theories and focusing on the Southern European area, Vignoli et al. (2012) found a strong, positive effect of men's income on first birth for Italy. Because of the persistence of the male breadwinner model in this area, it might be more important for men to become established professionally before having children.

In his successive works, Becker stated that high income for women is negatively associated with fertility because opportunity costs, or the indirect costs of raising children, are higher for women than for men (Becker, 1981). According to Joshi (1998), women's opportunity costs associated with higher income affect early childbearing in particular. An alternative view is presented by Oppenheimer (1994). Women's work, and thus income, protects households from risky life events, particularly the loss of the partner's job. However, for Italy, Rondinelli et al. (2010) found a negative relationship between women's income and first birth, showing that in Southern Europe, women with higher incomes might have high opportunity costs already with their first children.

Other studies have favoured the positive effect of high income of partners when jointly considered. In particular, a high household income can be positively associated with outsourcing strategies (Schneider and Hastings, 2017; De Ruijter et al. 2005). Thus, we might expect that both partners having high incomes has a positive effect on first birth because of outsourcing strategies, especially in a context such as Greece, where family policies are limited.

Our first hypothesis is the following: because of their higher financial resources and their outsourcing strategies, couples in which both partners have high incomes have a higher probability of having a first child than other couples. However, because of women's opportunity costs, couples in which the man has a high income are more likely to have a first child than couples in which the woman has a high income (and the man a low income). Note that, according to our assumptions, high income can have a positive or negative effect on fertility according to the combination of partners' income. We assume that the positive income effect on fertility prevails when both partners have a high income. This positive income effect should also exist when only the male partner has a high income. However, when only the female partner in the couple has a high income, we assume a negative effect of opportunity costs on fertility.

\section{Partners' work contracts and first birth}

Transition to parenthood is an irreversible choice producing long-term effects; thus, the stability of work of both partners (defined here as having a permanent contract) offers the best framework for parenthood. However, it has been assumed that women's instability (having a temporary contract) can have a positive effect on first birth. According to Friedman et al.'s (1994) theory of reduction of uncertainty, in periods of life uncertainty, for example, with reference to the labour market, parenthood can be a strategy to reduce uncertainty (see also Vignoli et al. (2016) for an application of the theory to transition to marriage). While the individual cannot control labour market conditions, parenthood is an available strategy producing permanent effects, thus reducing life uncertainty. This strategy applies especially to women, for whom the consequences of parenthood are more compelling.

Previous empirical findings regarding job instability and first birth did not support Friedman et al.'s (1994) theory of reduction of uncertainty. Studies of Italy and Spain showed that both 
partners having permanent contracts has positive effects on the birth of the first child (Barbieri et al. 2015; Vignoli et al. 2012; Barbieri, 2011). Pailhé and Solaz (2013), for France, and Liefbroer (2005), for the Netherlands, showed that having a permanent contract is more important for women than for men in the decision to have a first child. One explanation is that women with fixed-term contracts might risk losing their jobs after having children, so they prefer to find stable jobs before having their first child (Barbieri et al., 2015).

Thus, our second hypothesis is that in Greece, couples in which at least one partner has a temporary work contract are less likely to have a first birth than other couples.

\section{Partners' activity status and first birth}

Friedman et al.'s (1994) theory of reduction of uncertainty likely better applies to women who are inactive or unemployed. Unemployed women might seek to reduce their uncertainty in the labour market by becoming mothers. Inactive women might also have had difficulties in the labour market, or their devotion to the family might have been in anticipation of their difficulties. In both cases, becoming a mother represents the full achievement of their identity as a housewife and might be a strategy to reduce their uncertainty. According to another theoretical framework, inactive women might simply have preferences for caring for the family instead of investing in careers (Hakim, 2016). Also, according to this view, they should be more likely to have a first child.

Becker's economic models showed that the specialization of roles, with one partner devoted to paid labour and the other to unpaid labour, favours fertility (Becker, 1985). The partner specializing in unpaid labour is more often the female partner. This trend is observable especially in Greece, where women perform 92\% of housework (Ruppanner, 2010).

These theories were confirmed by previous empirical studies showing that in Italy, an unemployed woman is more likely to have a first child than a working woman (Cazzola et al., 2016). The same result was obtained by Cooke (2009) for Italy and Spain. Paihlé and Solaz (2012) showed that inactive women have considerably higher chances of having a first child than women with any other employment status (working, unemployed, student, or in short-term employment). A requirement for the positive association between a woman's inactivity and fertility is, however, her partner's employment (Paihlé and Solaz, 2012; Vignoli et al. 2012; Santarelli, 2011).

In our third hypothesis, we expect that couples in which women are inactive or unemployed and men are employed are more likely to have a first child than other couples.

\section{Partners' education and first birth}

The level of education is generally considered a proxy for income. Even when information about income is available, as in our study, education can still inform researchers about long-term economic prospects (Trimarchi and Van Bavel, 2017). Because of their investment in human capital and high expectations for the future, educated people might seek to establish themselves in their careers before having a first child. This mechanism could be observed especially for highly qualified women: since women still have the main responsibility for caring for the family (Ruppanner, 2010), more educated women's perceptions of opportunity costs (Joshi, 1998; Becker, 1981) might delay the birth of the first child. Moreover, according to Becker's quality-quantity tradeoff, more educated couples may prefer to wait before entering parenthood to accumulate sufficient resources to improve the "quality" of the child (Becker and Lewis 1973). 
While some studies did not find a significant effect of education on first birth (Vignoli et al. 2012; Skirbekk, 2008), Gutiérrez-Domènech (2008) found that a man's high education positively affects the likelihood of first birth. For highly educated women, a strong inverse relationship with the timing of first birth has generally been found (Balbo et al. 2013; Paihlé and Solaz, 2012; Gutiérrez-Domènech, 2008).

More generally, partners' education can inform us about partners' attitudes. According to the second demographic transition (SDT) theory, people delay entry into parenthood to promote self-realization (Vignoli, 2016; Lesthaeghe, 2010). In the typical path of diffusion underlined by the SDT, more educated people are the forerunners of the process, as well as those more concerned with the achievement of higher-order needs. Thus, according to this theory, a negative relationship between education and first birth can be assumed.

Fertility has been proposed to be more affected by gender relations than by adherence to higher-order needs (Goldscheider et al. 2015). From this perspective, we examine education as a proxy of partners' gender attitudes. More educated partners are found to be more likely to share household tasks more equally (Goldscheider et al. 2015; Davis and Greenstein, 2009; Coltrane, 2000). A highly educated male partner is more likely to be involved in family work, while a highly educated female partner might hold more power in the negotiation of this involvement (Lundberg and Pollak, 1996). The gender equity theory of fertility (McDonald, 2000) assumes a positive association between gender equity and fertility.

Thus, we should expect a positive relationship between fertility and the education levels of both partners.

Empirical studies of partners' education and first birth have not supported the gender theory of fertility. Some empirical studies that jointly considered the effect of the education of both partners on first birth did not find significant effects (Corijn et al. 1996; Jalovaara and Miettinen, 2013). An overall negative educational gradient of first birth was found by Trimarchi and Van Bavel (2017) and by Nitsche et al. (2018). For Greece, Bagavos (2017) showed that couples in which women are highly educated have later first births, especially if the men are less educated. These results support SDT, opportunity cost theory, the human capital argument, and preference of the quality of the child. Thus, in the fourth hypothesis of this study, we expect that homogamous, highly educated couples and highly hypogamous couples are less likely to have a first child than other couples.

\section{The Great Recession and fertility}

Not only individual economic uncertainty but also economic uncertainty as an aggregated phenomenon can affect the arrival of the first child. We can identify at least three mechanisms of the influence of the economic recession on first birth. First, economic recessions increase unemployment and job instability among young people, causing the objective economic conditions of families to deteriorate and thus depressing fertility. For Greece, it has been shown that the decline in male fertility during economic recessions is primarily due to the decrease in the proportion of employed men (Tragaki and Bagavos, 2014). A strong effect of unemployment on first birth has been found for the periods of 2001-2011 (Goldstein et al., 2013) and 2000-2013 (Comolli, 2017).

Second, a period of economic recession can worsen expectations about the future. This may result in an amplification of the effect of objective individual economic conditions on fertility (Sobotka et al. 2011). Thus, during economic recessions, couples in which partners have temporary contracts might be even less inclined to make irreversible choices, such as having a first child. Moreover, it is especially during economic recessions that 
women who are unemployed, inactive, and minimally educated might find parenthood more attractive than facing uncertainty in the labour market (Sobotka et al. 2011). In this respect, with reference to Greece, Bagavos and Tragaki (2017) showed that the pre-crisis period was characterized by strong differences in fertility rates between employed and non-employed men, but these differences were unimportant among women. After the onset of the crisis, employed women with high education and non-employed women with low education had the highest fertility rates (Bagavos and Tragaki, 2017).

In a third mechanism of the influence of economic recessions on first birth, the reconciliation of work and family can become more difficult because of the shrinkage of the welfare state and, in particular, of family policies (see the "The Greek context" section), thus reducing the likelihood of a first birth. In the context of shrinkage of the welfare state, wealthier and more educated people are more likely to have alternative strategies to balance family and work. Wealthier couples might outsource family work and therefore be in a more favourable position to have a first child than other couples.

Because of worsening expectations about the future, in our fifth hypothesis, we assume that during the economic recession, the likelihood of having a first child decreases.

In our sixth hypothesis, we assume that the recent economic recession can amplify or diminish the effect of some couples' characteristics on first birth. In particular, we expect that the crisis magnifies the positive effect of the male breadwinner model (employed men and inactive or unemployed women) on first birth. In other words, in an economic recession, staying at home and having a child can become more attractive, also because of the Greek welfare shrinkage occurring during the crisis that affected family policies. Finally, the recession should also amplify the positive effect of being in a couple where both partners have a high income and of being in a couple where both partners have a permanent contract. This amplification should happen because of partners' greater ability to outsource care activities compared to the ability of lower-income couples, who are more affected by the Greek welfare shrinkage occurring during the recession. In addition, the worsening expectations about the future that come with a recession should be less severe for these high-income and economically stable couples.

\section{Data and methods}

For the purposes of this paper, we used longitudinal data from the EU-SILC survey (EU Statistics on Income and Living Conditions). The EU-SILC survey was launched in 2003 as the continuation of the European Community Household Panel survey (ECHP, 1994-2000). The survey is the instrument used by the European Union to monitor progress on its Europe 2020 strategy, the main objective of which is to reduce poverty. To these ends, the EU-SILC survey collects comparable and multidimensional micro-level data on income, poverty, social exclusion, housing, work, education, and health. In Greece, the EU-SILC survey has been conducted since 2004, collecting longitudinal data on 3500 households and 7250 individuals per wave.

In this study, we focused on the period of 2005-2013, including 67,493 person-years of the Greek EU-SILC. We selected couples whose partners are childless and younger than 50 years old. We assumed that the possibility of having a first child in Greece exists almost exclusively for couples (see section "The Greek context"). For the sake of simplicity, we excluded individuals who live with children born from previous unions. As in Santarelli (2011), we excluded individuals living with adults other than their spouses because they might provide economic support to the household. Our final sample consists of 1974 
couple-years and 1185 couples. For the period of analysis, we observed 136 first births. In the EU-SILC database, new births are identified under the variable "membership status" in the category "newly born into the household since the last wave". We created the variable "First birth," which takes the value of 1 when there is a newborn (variable ...) in a household included in the previous wave by two members (variable "hx040") being in partnership (variable "pb200").

To study the effect of individual income, we first grouped men's and women's income into two categories based on their median yearly incomes: $€ 6,403$ in the case of women and $€ 13,871$ in the case of men. Subsequently, we created the new variable "couples' income", which includes four categories: (1) "high-low" couples, in which the male partner's income is high $(>€ 13,871)$ and the female partner's income is low $(\leq € 6,403) ;(2)$ "low-high" couples, in which the male partner's income is low $(\leq € 13,871)$ and the female partner's income is high $(\leq € 6,403)$; (3) "low-low" couples, in which both partners have a low income; and (4) "high-high" couples, in which both partners have a high income. For problems related to the size of the sample, models $1-3$ of Table 2 are estimated for all men and women. Thus, the income information includes zero income.

The variable "couple's contract duration" contains two categories: (1) at least one partner temporary and (2) woman's permanent-man's permanent. Moreover, by combining the variables of women's activity status with those of their partners, we created the variable "couple's activity status," which is recoded into four categories: (1) inactive or unemployed womanemployed man, (2) employed woman-employed man, (3) employed woman-inactive or unemployed man, and (4) inactive or unemployed man-inactive or unemployed man.

For couples' education, we referred to the variable "highest ISCED level attained" (International Standard Classification of Education). We first grouped individuals into three categories: (1) low educational level, including pre-primary, primary (Demotiko), or lower secondary school (Gymnasio) education; (2) intermediate educational level, including upper secondary (Lykeio) or non-tertiary education; and (3) high educational level, including tertiary education (bachelor's, master's, or doctorate degrees). We then created a new variable to represent a couple's education, with five categories: (1) couples in which the male partner's educational level is higher ("man's higher"); (2) couples in which the woman's educational level is higher ("woman's higher"); (3) homogamous couples with a low education level ("low-low"); (4) homogamous couples with a medium education level ("medium-medium"); and (5) homogamous couples with a high education level ("highhigh"). To study how the economic crisis affected fertility, we created the variable "calendar time". In this study, we chose to define 2008 as the year in which the crisis began. For this reason, this variable contains two categories: (1) 2005-2009 and (2) 2010-2013.

Our control variables are the woman's age, marital status, region of residence, and degree of urbanization. Age is recoded into five categories: (1) up to 24 years, (2) 25 to 29 years, (3) 30 to 34 years, (4) 35 to 39 years, and (5) 40 to 49 years. The variable "union" is coded as follows: (1) union with a legal basis and (2) union without a legal basis (de facto partners living in the same household). Regarding the place of residence of the respondents, we used two variables: "region" and "degree of urbanization". Concerning the region of residence, in the SILC database, a NUTS 1 classification of territorial units is available. NUTS 1 corresponds to four "development areas" that aggregate Greece's 13 regions (without necessarily constituting official administrative units): (1) Northern Greece (Anatoliki Makedonia, Thraki, Kentriki Makedonia, Dytiki 
Makedonia, and Thessalia); (2) Central Greece (Ipeiros, Sterea Ellada, Dytiki Ellada, and Pelopponisos); (3) Attiki; and (4) the Aegean Islands and Crete (Voreio Aigaio, Notio Aigaio, and Kriti). Regarding the degree of urbanization, we used three categories corresponding to those proposed by the EU-SILC: (1) sparsely populated area, (2) intermediate area, and (3) densely populated area.

Regarding the estimation method, it is not advisable to use ordinary logistic regression with panel data because of the correlation between observations for the same person, which can cause biased standard errors. The use of logistic random effects regression models in this study allows us to consider this correlation (Li et al. 2011; Mood, 2010; Rabe-Hesketh and Skrondal, 2008). Other models (not used here) that account for this correlation, such as the fixed effects model with conditional likelihood, have the inconvenience of estimating coefficients only for the time-varying explanatory variables.

Finally, childbearing is the result of a decisional process in which economic factors influence first birth with a delay of at least 9 months. According to Pailhé (2010), demographic trends follow economic trends with a 1- or 2-year lag. In this study, we assumed that the decision to have a first birth is made 1 year earlier, and the relevant explanatory factors are lagged by 1 year.

\section{Results}

Descriptive analysis of our sample

In our sample composed of childless couples, $87 \%$ are in legal unions (Table 1). Hypogamy is more frequent than hypergamy: the female partner has a higher education level than the male partner in $21 \%$ of couples, while the male partner has a higher education level than the female partner in $15 \%$ of couples (Table 1), confirming recent empirical evidence of a "reversal of gender inequality in education" in developed countries in recent years (Van Bavel, 2012).

In $29 \%$ of couples, the man is employed, and the woman is inactive or unemployed. In $52.5 \%$ of couples, both partners are employed. In addition, among employed partners, in $70.7 \%$ of cases, both have permanent contracts (Table 1). This relatively high percentage shows that young adults without a stable employment status are more likely to avoid entering into a union (Aassve et al., 2006).

When comparing the period of 2005-2009 with the period of 2010-2013, we observed that some notable changes occurred with the economic crisis. While the share of dual-earner couples decreased from 58 to $46 \%$, the share of male breadwinner households (employed man-unemployed/inactive woman) increased from 27 to $31 \%$, together with the share of female breadwinner couples (employed woman-unemployed/inactive man), from 7 to 14\% (Table 3 in the Appendix). Couples where both partners have a high income decreased from 34 to $28 \%$, while we observed an increase in couples where women have a higher income than the median and men a lower income than the median, from 20 to $24 \%$ (Table 1).

\section{The effect of economic uncertainty on first birth}

The estimated random effects models (Table 2, models 1-5) showed strong and statistically significant effects on first birth due to the economic crisis, partners' education levels, partners' incomes, and partners' activity status. 
Table 1 Descriptive statistics for the variables used in the study

\begin{tabular}{|c|c|c|c|}
\hline & Percentage & Obs. & 1st child \\
\hline \multicolumn{4}{|l|}{ Couple's education } \\
\hline Man's higher & 14.58 & 254 & 6 \\
\hline Woman's higher & 20.72 & 361 & 32 \\
\hline Low-low & 17.34 & 302 & 11 \\
\hline Medium-medium & 25.32 & 441 & 38 \\
\hline High-high & 22.04 & 384 & 46 \\
\hline \multicolumn{4}{|l|}{ Couple's activity status } \\
\hline Unemployed/inactive woman-employed man & 28.59 & 500 & 36 \\
\hline Employed woman-employed man & 52.48 & 918 & 92 \\
\hline Employed woman-unemployed/inactive man & 10.18 & 176 & 2 \\
\hline Unemployed/inactive woman-unemployed/inactive man & 8.75 & 153 & 3 \\
\hline \multicolumn{4}{|l|}{ Couple's income } \\
\hline Woman's high-man's low & 21.82 & 378 & 32 \\
\hline Man's high-woman's low & 20.79 & 360 & 20 \\
\hline Low-low & 26.15 & 453 & 24 \\
\hline High-high & 31.24 & 541 & 56 \\
\hline \multicolumn{4}{|l|}{ Calendar time } \\
\hline 2005-2009 & 54.46 & 1075 & 98 \\
\hline 2010-2013 & 45.54 & 899 & 38 \\
\hline \multicolumn{4}{|l|}{ Woman's age } \\
\hline Up to 24 & 5.92 & 101 & 13 \\
\hline $25-29$ & 17.42 & 297 & 33 \\
\hline $30-34$ & 21.29 & 363 & 64 \\
\hline $35-39$ & 14.84 & 253 & 19 \\
\hline $40-49$ & 40.53 & 691 & 7 \\
\hline \multicolumn{4}{|l|}{ Marital status } \\
\hline Legal union & 87.11 & 1601 & 125 \\
\hline Other union & 12.89 & 237 & 11 \\
\hline \multicolumn{4}{|l|}{ Area of residence } \\
\hline Voreia Ellada (Northern Greece) & 36.34 & 668 & 52 \\
\hline Kentriki Ellada (Central Greece) & 21.16 & 389 & 20 \\
\hline Attiki & 32.54 & 598 & 46 \\
\hline Aigaio and Kriti (Aegean Islands and Crete) & 9.96 & 183 & 18 \\
\hline \multicolumn{4}{|l|}{ Degree of urbanization } \\
\hline Densely populated area & 42.6 & 783 & 60 \\
\hline Intermediate area & 12.84 & 236 & 25 \\
\hline Sparsely populated area & 44.56 & 819 & 51 \\
\hline \multicolumn{4}{|l|}{ Couple's type of contract } \\
\hline At least one partner temporary & 29.26 & 158 & 10 \\
\hline Woman's permanent-man's permanent & 70.74 & 382 & 41 \\
\hline
\end{tabular}

Source: Authors' own calculations based on the European Union Statistics on Income and Living Conditions 2013

As expected, the economic crisis affected couples' choice to have a first child. Couples had 2.1 times higher probability (equal to $1 / 0.47$ ) of having a first child during the pre-crisis period of 2005-2009 than during the crisis period of 2010-2013 (Table 2, model 1 without interactions). 
Table 2 Transition to first child in Greece; random effects models

\begin{tabular}{|c|c|c|c|c|c|}
\hline & $\begin{array}{l}\text { Model 1, } \\
\text { OR }\end{array}$ & $\begin{array}{l}\text { Model 2, } \\
\text { OR }\end{array}$ & $\begin{array}{l}\text { Model 3, } \\
\text { OR }\end{array}$ & $\begin{array}{l}\text { Model 4, } \\
\text { OR }\end{array}$ & $\begin{array}{l}\text { Model 5, } \\
\text { OR }\end{array}$ \\
\hline \multicolumn{6}{|l|}{ Main variables } \\
\hline \multicolumn{6}{|l|}{$\begin{array}{l}\text { Couple's activity status (Ref = employed woman- } \\
\text { employed man) }\end{array}$} \\
\hline Unemployed/inactive woman-employed man & 1.11 & 1.08 & 1.09 & 1.66 & \\
\hline Employed woman-unemployed/inactive man & $0.18^{* *}$ & $0.17^{* *}$ & $0.21^{*}$ & 0.56 & \\
\hline $\begin{array}{l}\text { Unemployed/inactive woman-unemployed/ } \\
\text { inactive man }\end{array}$ & 0.38 & 0.38 & 0.31 & $0.16^{*}$ & \\
\hline \multicolumn{6}{|l|}{ Couple's income (Ref $=$ low-low) } \\
\hline Woman's high-man's low & 1.89 & 1.42 & 1.89 & 1.96 & 2.73 \\
\hline Man's high-woman's low & 1.76 & $2.31^{*}$ & 1.72 & 1.77 & 2.91 \\
\hline High-high & $2.12^{*}$ & 1.57 & $2.11^{*}$ & $2.26^{*}$ & 3.69 \\
\hline \multicolumn{6}{|l|}{$\begin{array}{l}\text { Couple's type of contract }(\operatorname{Ref}=\text { at least one } \\
\text { partner temporary) }\end{array}$} \\
\hline Woman's permanent-man's permanent & & & & & $3.65^{* *}$ \\
\hline \multicolumn{6}{|l|}{ Couple's education (Ref = man's higher) } \\
\hline Woman's higher & $2.97^{* *}$ & $2.95^{*}$ & $5.47^{* *}$ & $3.01^{*}$ & 4.2 \\
\hline Low-low & 2.41 & 2.27 & $5.72^{* *}$ & 2.56 & \\
\hline Medium-medium & $2.62^{*}$ & $2.73^{*}$ & $3.64^{*}$ & $2.57^{*}$ & $6.99^{*}$ \\
\hline High-high & $3.56^{* *}$ & $3.66^{* *}$ & $5.28^{* *}$ & $3.57^{* *}$ & $10.14^{* *}$ \\
\hline \multicolumn{6}{|l|}{ Calendar time $(\operatorname{Ref}=2005-2009)$} \\
\hline 2010-2013 & $0.47^{* * *}$ & $0.43^{* *}$ & 1.57 & 0.67 & 2.82 \\
\hline \multicolumn{6}{|l|}{ Interaction terms } \\
\hline \multicolumn{6}{|l|}{ Couple's education $\times$ time } \\
\hline Woman's higher $\times$ time & & 0.18 & & & \\
\hline Low-low $\times$ time & & / & & & \\
\hline Medium-medium $\times$ time & & 0.43 & & & \\
\hline High-high $\times$ time & & 0.36 & & & \\
\hline \multicolumn{6}{|l|}{ Couple's activity status $\times$ time } \\
\hline $\begin{array}{l}\text { Unemployed/inactive woman-Employed man } \times \\
\text { time }\end{array}$ & & & $0.29^{* *}$ & & \\
\hline $\begin{array}{l}\text { Employed woman-unemployed/inactive man } \times \\
\text { time }\end{array}$ & & & / & & \\
\hline $\begin{array}{l}\text { Unemployed/inactive woman-unemployed/ } \\
\text { inactive man }\end{array}$ & & & 4.47 & & \\
\hline \multicolumn{6}{|l|}{ Partners income $\times$ time } \\
\hline Woman's income high-man's low $\times$ time & & & & 1.94 & \\
\hline Man's income high-woman's low $\times$ time & & & & 0.14 & \\
\hline Woman's and man's income high $\times$ time & & & & 2.06 & \\
\hline \multicolumn{6}{|l|}{ Couple's type of contract $\times$ time } \\
\hline Woman's permanent-man's permanent $\times$ time & & & & & $0.19^{*}$ \\
\hline No. of couples & 1592 & 1592 & 1492 & 1497 & 482 \\
\hline Log pseudolikelihood & -362.8 & -357.4 & -357.9 & -357.3 & -137.3 \\
\hline
\end{tabular}

*** $p<0.01 ;{ }^{* *} p<0.05 ;{ }^{*} p<0.1$. Control variables are woman's age, marital status, area of residence, and degree of urbanization. Model 5 refers to working women 
Contrary to our expectations, we observed that the higher the partners' education level was, the greater the likelihood of them having their first child (Table 2, model 1). Couples in which the woman is more educated than the man are also more likely to have a first child than couples in which the man is more educated (Table 2, model 1). Moreover, couples' income significantly affects first birth. In particular, couples where both partners have a high income are 2.1 times more likely to have a first child than couples where both partners have a low income (Table 2, model 1).

Our results also showed the impact of couples' activity status on the occurrence of a first birth. Dual-earner couples have a greater likelihood of having a first birth than couples in which the male partner is unemployed or inactive $(\mathrm{OR}=5.5=1 / 0.18$, Table 2 , model 4$)$. Regarding the interaction between the couple's activity status and the dummy "2010-2013," male breadwinner couples are less likely to have a first child during the economic crisis than couples where both partners are employed in the period 2005-2009 (Table 2, model 3). The interaction indicates an OR lower than zero (or negative coefficient). Summing the coefficients (lnOR) of the main effect of this variable with the coefficients of the interaction with the period, we observe that the total effect of the male breadwinner model during the economic crisis is negative, corresponding to an $\mathrm{OR}=\exp (-1.15)=0.32$.

Finally, regarding the type of contract, couples where both partners have a permanent contract seem more likely to have a first birth, although the result is not statistically significant (Table 4 in the Appendix, model 9). However, the effect becomes statistically significant in interaction with the variable "period" (Table 2, model 5). In this case, summing for this variable the coefficients (lnOR) of the main effect and of the interaction effect, we obtain -0.37 , giving an $\mathrm{OR}=\exp (-0.37)=0.69$. The OR equal to $1 / 0.69=1.44$ indicates a surprising result: during the economic crisis, couples with at least one partner with a temporary work, usually the woman, have an odds to have a first child $44 \%$ higher than couples where both partners have a permanent work in the period 2005-2009.

Overall, when looking at the nested models in the Appendix, we observe that the main effects of the explanatory variables only slightly change when the control variables are added to the model, indicating robustness in the value and direction of the effect on first birth (Table 4 in the Appendix).

\section{Discussion and conclusions}

Our study showed that individual economic uncertainty strongly affects the arrival of the first child in Greece. However, the effect depends on the indicators that we consider. Having both partners with a high income favours the arrival of the first birth, partially confirming our first hypothesis and emphasizing that the decision to have a first child can be made in consideration of their ability to outsource care work and household tasks (Schneider and Hastings, 2017; De Ruijter et al. 2005; Coltrane, 2000). Couples where both partners have a permanent contract are also more likely to have a first child, supporting our second hypothesis and previous studies (Barbieri et al., 2015; Vignoli, 2012; Barbieri, 2011). However, contrary to our third hypothesis, we do not find statistically significant evidence of a higher likelihood of having a first child for male breadwinner couples than for dual-earner couples.

When considering the level of education, we found that highly homogamous couples are more likely to have a first child than hypergamous couples (where the man's education is higher). This finding was in opposition to our fourth hypothesis and to previous 
empirical studies. Nitsche et al. (2018) found a negative effect of education on first birth in Nordic and Western European countries but not in Southern Europe. This result by European regions may be explained by studies showing the tendency of young people to delay exiting the parental home in Southern European countries (Hank 2007; Aassve et al., 2006). Thus, in these countries, the accumulation of resources could be a prerequisite for entry into unions (or marriages), especially for the more educated. Thus, once they marry, more educated couples might already be prepared to have a first child and more quickly become parents. Our observation of a positive effect on first birth in the case of hypogamous couples (where women are more educated) might mean that preconditions for marriage, such as satisfactory resources and returns on human capital, can be especially important for women. Other plausible explanations for the positive effects of high homogamy and high hypogamy on first birth are the greater involvement in the family by highly educated men (Goldscheider et al., 2015; Coltrane, 2000 ), the greater power of highly educated women in negotiating this involvement, and the higher propensity to purchase domestic and care services (Coltrane, 2000).

Regarding economic uncertainty as an aggregate phenomenon, we found that the Great Recession had a strong, negative effect on first birth: during the years, 20102013, the likelihood of having a child decreased to half the value in the period of 20052009, supporting our fifth hypothesis. Moreover, the economic recession interacts with some couples' characteristics, although our sixth hypothesis is not supported. In fact, during the economic recession, male breadwinner couples became even less likely to have a first child than couples where both partners are employed. These results contradict our previous assumptions based on the shortage of work and shrinkage of the welfare state. Moreover, surprisingly, couples in which both partners had a permanent contract were less likely to have a first birth during the Great Recession. One interpretation is that lower prospects during the crisis may have convinced temporary workers, more often women, to have a first child.

In summary, our study showed the negative role of individual economic uncertainty on first birth in Greece. Greek couples where both partners are employed, have a high income, or are highly educated are in a more favourable position to have a first child. We also demonstrated the overall negative effect of the Great Recession on transition to first birth, indicating the worsening of partners' expectations about the future. Moreover, male breadwinner couples were less likely to have a first child during the Great Recession (2010-2013) than dual-earner couples in the previous period (2005-2009). This may be explained by the vulnerability of single-earner couples in the recession period, when the consequences of losing one's job may be more critical for the sole earner.

To conclude, we must remember the main limitations of our study. First, since we consider couples living independently of their parents, our sample could include individuals who were able to leave the parental home. Second, because of the small size of our sample, we are unable to disentangle the effect of a single year of the crisis. Despite these limitations, this study is one of the rare studies investigating fertility in Greece and shows the effects of the recent economic recession.

Since 2014, the negative trend in fertility seems to have stopped (Eurostat database accessed in May 2019). However, the demographic situation in Greece remains dire, with its fertility rate among the lowest in Europe. It is an appropriate time to remember that "the kingdom belongs to a child" (Heraclitus). 


\section{Appendix}

Table 3 Descriptive statistics for the variables used in the study according to time period (20052009; 2010-2013)

\begin{tabular}{|c|c|c|c|c|}
\hline & \multicolumn{2}{|l|}{$2005-2009$} & \multicolumn{2}{|l|}{$2010-2013$} \\
\hline & Percentage & Obs. & Percentage & Obs. \\
\hline \multicolumn{5}{|l|}{ Couple's education } \\
\hline Man's higher & 13.68 & 128 & 15.63 & 126 \\
\hline Woman's higher & 20.19 & 189 & 21.34 & 172 \\
\hline Low-low & 19.02 & 178 & 15.38 & 124 \\
\hline Medium-medium & 23.93 & 224 & 26.92 & 217 \\
\hline High-high & 23.18 & 217 & 20.72 & 167 \\
\hline \multicolumn{5}{|l|}{ Couple's activity status } \\
\hline Unemployed/inactive woman-employed man & 26.54 & 250 & 30.98 & 250 \\
\hline Employed woman-employed man & 57.96 & 546 & 46.1 & 372 \\
\hline Employed woman-unemployed/inactive man & 7.11 & 67 & 13.75 & 111 \\
\hline Unemployed/inactive woman-unemployed/inactive man & 8.39 & 79 & 9.17 & 74 \\
\hline \multicolumn{5}{|l|}{ Couple's income } \\
\hline Woman's high-man's low & 19.83 & 185 & 24.16 & 193 \\
\hline Man's high-woman's low & 21.01 & 196 & 20.53 & 164 \\
\hline Low-low & 24.97 & 233 & 27.53 & 220 \\
\hline High-high & 34.19 & 319 & 27.78 & 222 \\
\hline \multicolumn{5}{|l|}{ Calendar time } \\
\hline 2005 & 8.56 & 92 & & \\
\hline 2006 & 15.81 & 170 & & \\
\hline 2007 & 21.58 & 232 & & \\
\hline 2008 & 32.74 & 352 & & \\
\hline 2009 & 21.3 & 229 & & \\
\hline 2010 & & & 33.04 & 297 \\
\hline 2011 & & & 31.15 & 280 \\
\hline 2012 & & & 18.91 & 170 \\
\hline 2013 & & & 16.91 & 152 \\
\hline \multicolumn{5}{|l|}{ Woman's age } \\
\hline Up to 24 & 6.11 & 57 & 5.7 & 44 \\
\hline $25-29$ & 18.65 & 174 & 15.93 & 123 \\
\hline $30-34$ & 23.37 & 218 & 18.78 & 145 \\
\hline $35-39$ & 14.15 & 132 & 15.67 & 121 \\
\hline $40-49$ & 37.73 & 352 & 43.91 & 339 \\
\hline \multicolumn{5}{|l|}{ Marital status } \\
\hline Legal union & 86.1 & 855 & 88.28 & 746 \\
\hline Other union & 13.9 & 138 & 11.72 & 99 \\
\hline \multicolumn{5}{|l|}{ Area of residence } \\
\hline Voreia Ellada (Northern Greece) & 37.87 & 376 & 34.56 & 292 \\
\hline Kentriki Ellada (Central Greece) & 17.22 & 171 & 25.8 & 218 \\
\hline Attiki & 34.94 & 347 & 29.7 & 251 \\
\hline Aigaio and Kriti (Aegean Islands and Crete) & 9.97 & 99 & 9.94 & 84 \\
\hline
\end{tabular}

Degree of urbanization 
Table 3 Descriptive statistics for the variables used in the study according to time period (20052009; 2010-2013) (Continued)

\begin{tabular}{|c|c|c|c|c|}
\hline & \multicolumn{2}{|l|}{ 2005-2009 } & \multicolumn{2}{|l|}{$2010-2013$} \\
\hline & Percentage & Obs. & Percentage & Obs. \\
\hline Densely populated area & 45.82 & 455 & 38.82 & 328 \\
\hline Intermediate area & 13.49 & 134 & 12.07 & 102 \\
\hline Sparsely populated area & 40.68 & 404 & 49.11 & 415 \\
\hline \multicolumn{5}{|l|}{ Couple's type of contract } \\
\hline At least one partner temporary & 29.19 & 101 & 29.38 & 57 \\
\hline Both partners permanent & 70.81 & 245 & 70.62 & 137 \\
\hline
\end{tabular}

Source: Authors' own calculations based on the European Union Statistics on Income and Living Conditions 2013

Table 4 Transition to first child in Greece, nested random effects models (without interactions)

\begin{tabular}{|c|c|c|c|c|c|c|c|c|c|}
\hline & $\begin{array}{l}\text { Model } \\
1\end{array}$ & $\begin{array}{l}\text { Model } \\
2\end{array}$ & $\begin{array}{l}\text { Model } \\
3\end{array}$ & $\begin{array}{l}\text { Model } \\
4\end{array}$ & $\begin{array}{l}\text { Model } \\
5\end{array}$ & $\begin{array}{l}\text { Model } \\
6\end{array}$ & $\begin{array}{l}\text { Model } \\
7\end{array}$ & $\begin{array}{l}\text { Model } \\
8\end{array}$ & $\begin{array}{l}\text { Model } \\
9\end{array}$ \\
\hline & OR & OR & OR & OR & OR & OR & OR & OR & OR \\
\hline \multicolumn{10}{|l|}{$\begin{array}{l}\text { Couple's activity status } \\
\text { (Ref = Employed woman- } \\
\text { Employed man) }\end{array}$} \\
\hline $\begin{array}{l}\text { Unemployed/inactive } \\
\text { woman-employed man }\end{array}$ & $0.61^{*}$ & 0.98 & 1.03 & 1.15 & 1.09 & 1.09 & 1.09 & 1.11 & / \\
\hline $\begin{array}{l}\text { Employed woman- } \\
\text { unemployed/inactive man }\end{array}$ & $0.05^{* * *}$ & $0.06^{* * *}$ & $0.07^{* * *}$ & $0.1^{* * *}$ & $0.18^{* *}$ & $0.18^{* *}$ & $0.17^{* *}$ & $0.18^{* *}$ & / \\
\hline $\begin{array}{l}\text { Unemployed/inactive } \\
\text { woman-unemployed/ } \\
\text { inactive man }\end{array}$ & $0.1^{* * *}$ & $0.17^{* * *}$ & $0.21^{* *}$ & $0.27^{*}$ & 0.39 & 0.4 & 0.36 & 0.38 & / \\
\hline \multicolumn{10}{|l|}{$\begin{array}{l}\text { Couple's income }(\text { Ref }=\text { low- } \\
\text { low) }\end{array}$} \\
\hline Woman's high-man's low & & 1.94 & 1.31 & 1.41 & 1.59 & 1.83 & 1.89 & 1.89 & 1.88 \\
\hline Man's high-woman's low & & 0.93 & 0.86 & 0.83 & 1.69 & 1.61 & 1.76 & 1.76 & 1.94 \\
\hline High-high & & $2.01^{*}$ & 1.29 & 1.26 & 1.73 & 1.78 & $2.1^{*}$ & $2.12^{*}$ & 2.31 \\
\hline \multicolumn{10}{|l|}{$\begin{array}{l}\text { Couple's education (Ref = man's } \\
\text { higher) }\end{array}$} \\
\hline Woman's higher & & & $5.94^{* * *}$ & $4.66^{* * *}$ & $3.27^{* *}$ & $3.36^{* *}$ & $3.09^{* *}$ & $2.97^{* *}$ & 3.92 \\
\hline Low-low & & & 1.93 & 1.67 & $3.08^{* *}$ & $2.63^{*}$ & 2.41 & 2.41 & / \\
\hline Medium-medium & & & $5.42^{* * *}$ & $4.42^{* * *}$ & $2.81^{* * *}$ & $2.76^{*}$ & $2.69^{*}$ & $2.62^{*}$ & $6.48^{*}$ \\
\hline High-high & & & $8.01 * * *$ & $5.95^{* * *}$ & $3.42^{* *}$ & $3.62^{* *}$ & $3.49^{* *}$ & $3.56^{* *}$ & $9.59^{*}$ \\
\hline \multicolumn{10}{|l|}{$\begin{array}{l}\text { Calendar time }(\text { Ref }=2005- \\
\text { 2009) }\end{array}$} \\
\hline 2010-2013 & & & & $0.41^{* * *}$ & $0.49^{* * *}$ & $0.48^{* * *}$ & $0.47^{* * *}$ & $0.47^{* * *}$ & 0.81 \\
\hline \multicolumn{10}{|l|}{ Woman's age $(\operatorname{Ref}=30-34)$} \\
\hline Up to 24 & & & & & 1.2 & 1.94 & 1.89 & 1.79 & 1.23 \\
\hline $25-29$ & & & & & $0.6^{*}$ & 0.72 & 0.67 & 0.66 & 0.54 \\
\hline $35-39$ & & & & & $0.39^{* * *}$ & $0.37^{* * *}$ & $0.36^{* * *}$ & $0.36^{* * *}$ & 0.83 \\
\hline $40-49$ & & & & & $0.04^{* * *}$ & $0.04^{* * *}$ & $0.04^{* * *}$ & $0.04^{* * *}$ & $0.05^{* * *}$ \\
\hline \multicolumn{10}{|l|}{$\begin{array}{l}\text { Marital status }(\text { Ref }=\text { other } \\
\text { union) }\end{array}$} \\
\hline Legal union & & & & & & $4.62^{* * *}$ & $5.03^{* * *}$ & $4.58^{* * *}$ & 1.9 \\
\hline
\end{tabular}


Table 4 Transition to first child in Greece, nested random effects models (without interactions) (Continued)

\begin{tabular}{|c|c|c|c|c|c|c|c|c|c|}
\hline & $\begin{array}{l}\text { Model } \\
1\end{array}$ & $\begin{array}{l}\text { Model } \\
2\end{array}$ & $\begin{array}{l}\text { Model } \\
3\end{array}$ & $\begin{array}{l}\text { Model } \\
4\end{array}$ & $\begin{array}{l}\text { Model } \\
5\end{array}$ & $\begin{array}{l}\text { Model } \\
6\end{array}$ & $\begin{array}{l}\text { Model } \\
7\end{array}$ & $\begin{array}{l}\text { Model } \\
8\end{array}$ & $\begin{array}{l}\text { Model } \\
9\end{array}$ \\
\hline & OR & OR & OR & OR & OR & OR & OR & OR & OR \\
\hline $\begin{array}{l}\text { Voreia Ellada (Northern } \\
\text { Greece) }\end{array}$ & & & & & & & $2.28^{* * *}$ & $2.13^{* *}$ & $2.15^{*}$ \\
\hline $\begin{array}{l}\text { Kentriki Ellada (Central } \\
\text { Greece) }\end{array}$ & & & & & & & 1.65 & 1.59 & 1.69 \\
\hline $\begin{array}{l}\text { Aigaio and Kriti (Aegean } \\
\text { Islands and Crete) }\end{array}$ & & & & & & & $2.27^{* *}$ & $2.13^{*}$ & 2.36 \\
\hline \multicolumn{10}{|l|}{$\begin{array}{l}\text { Degree of urbanization } \\
\text { (densely populated area) }\end{array}$} \\
\hline Intermediate area & & & & & & & & 1.56 & 1.13 \\
\hline Sparsely populated area & & & & & & & & 1.26 & $2.36^{*}$ \\
\hline \multicolumn{10}{|l|}{$\begin{array}{l}\text { Couple's type of contract } \\
\text { (Ref = at least one partner } \\
\text { temporary) }\end{array}$} \\
\hline $\begin{array}{l}\text { Woman's permanent-man's } \\
\text { permanent }\end{array}$ & & & & & & & & & 1.92 \\
\hline No. of couples & 1749 & 1729 & 1719 & 1719 & 1592 & 1592 & 1592 & 1592 & 461 \\
\hline Log pseudolikelihood & -449.5 & - & - & - & $-\overline{378.1}$ & - & - & $-\overline{362.8}$ & - \\
\hline
\end{tabular}

${ }^{* * *} p<0.01 ; * * 0<0.05 ;{ }^{*} p<0.1$

\section{Acknowledgements}

We would like to thank Li Ma, Thomas Baudin, Thierry Eggerickx, participants in the seminar "Midi de la recherche" at the Center for Demographic Research of the Université Catholique de Louvain, and participants at the 2016 ARC workshop "Family transformations: Incentives and Norms" for their valuable comments and suggestions on earlier versions of this article.

\section{Authors' contributions}

CD initiated the project, worked on the literature review, and performed the data analyses. ER helped with the application of the hypothetico-deductive approach and with the interpretation of the findings. She also contributed to the literature review section. Both authors were involved in drafting the manuscript. Both authors read and approved the final manuscript.

\section{Funding}

The work was supported by the Fonds de la Recherch Scientifique (FNRS), grant $\langle$ T.0142.15 $>$, and by the Universite Catholique de Louvain Grant ARC "Family transformations: incentives and norms."

\section{Availability of data and materials}

For the analysis, we used data from the EU-SILC, which are available upon request at https://ec.europa.eu/eurostat/ web/microdata/overview.

All of the calculations were performed in Stata software, version 15

\section{Competing interests}

The authors declare that they have no competing interests.

Received: 7 October 2018 Accepted: 25 October 2019

Published online: 07 January 2020

\section{References}

Aassve, A., lacovou, M., \& Mencarini, L. (2006). Youth poverty and transition to adulthood in Europe. Demographic Research, 15(2), 21-50.

Aasve, A., Cottin, E., \& Vitali, A. (2013). Youth prospects in a time of economic recession. Demographic Research, 29(36), 949962.

Adsera, A. (2011). Where are the babies? Labor market conditions and fertility in Europe. European Journal of Population/Revue européenne de Démographie, 27(1), 1-32.

Albertini, M., Kohli, M., \& Vogel, C. (2007). Intergenerational transfers of time and money in European families: Common patterns - different regimes. Journal of European Social Policy, 17(4), 319-334.

Bagavos, C. (2017). Do different educational pairings lead to different fertility outcomes? A cohort perspective for the Greek case. Vienna Yearbook of Population Research, 15, 215-237. 
Bagavos, C., \& Tragaki, A. (2017). The compositional effects of education and employment on Greek male and female fertility rates during 2000-2014. Demographic Research, 36(47), 1435-1452.

Balbo, N., Billari, F., \& Mills, M. (2013). Fertility in advanced societies: A review of research. European Journal of Population, 29, 1-38.

Barbieri, P. (2011). Italy: No country for young men (and women): The Italian way of coping with increasing demands for labour market flexibility and rising welfare problems. Globalized labour markets and social inequality in Europe, $108-148$.

Barbieri, P., \& Bozzon, R. (2016). Welfare, labour market deregulation and households' poverty risks: An analysis of the risk of entering poverty at childbirth in different European welfare clusters. Journal of European Social Policy, 26(2), 99-123.

Barbieri, P., Bozzon, R., Scherer, S., Grotti, R., \& Lugo, M. (2015). The rise of a Latin model? Family and fertility consequences of employment instability in Italy and Spain. European Societies, 17(4), 423-446.

Becker, G. (1981). A Treatise on the Family. Cambridge, MA: Harvard UniversityPress.

Becker, G. S. (1960). An economic analysis of fertility. In G. S. Becker (Ed.), Demographic and economic change in developed countries (pp. 209-231). Princeton: Princeton University Press.

Becker, G. S. (1985). Human capital, effort, and the sexual division of labor. Journal of Labor Economics, 3(1), 533-558.

Becker, G. S., \& Lewis, H. G. (1973). On the interaction between the quantity and quality of children. Journal of Political Economy, 81 (2, Part 2), S279-S288.

Billari, F. (2008). Lowest-low fertility in Europe: Exploring the causes and finding some surprises. The Japanese Journal of Population, 6(1), 2-18.

Blossfeld, H. P., Klijzing, E., Mills, M., \& Kurz, K. (2005). Globalization, uncertainty and youth in society (pp. 1-24). London and New York: Routledge.

Bongaarts, J., \& Feeney, G. (1998). On the quantum and tempo of fertility. Population and development review, 271-291.

Buchholz, S., Hofacker, D., Mills, M., Blossfeld, H. P., Kurz, K., \& Hofmeister, H. (2009). Life courses in the globalization process: The development of social inequalities in modern societies. European Sociological Review, 25(1), 53-71.

Caltabiano, M., Castiglioni, M., \& Rosina, A. (2009). Lowest-low fertility: Signs of a recovery in Italy? Demographic Research, 21, 681-718.

Cazzola, A., Pasquini, L., \& Angeli, A. (2016). The relationship between unemployment and fertility in Italy: a time-series analysis. Demographic Research, 34(1), 1-38.

Coltrane, S. (2000). Research on household labor: Modeling and measuring the social embeddedness of routine family work. Journal of Marriage and the Family, 62(4), 1208-1233.

Comolli, C. L. (2017). The fertility response to the Great Recession in Europe and the United States: Structural economic conditions and perceived economic uncertainty. Demographic Research, 36(51), 1549-1600.

Cooke, L. P. (2009). Gender equity and fertility in Italy and Spain. Journal of Social Policy, 38(1), 123-140.

Corijn, M., Liefbroer, A. C., \& Gierveld, J. J. (1996). It takes two to tango, doesn't it? The influence of couple characteristics on the timing of the birth of the first child. Journal of Marriage and Family, 58(1), 117-126.

Dalla Zuanna, G. (2001). The banquet of Aeolus: A familistic interpretation of Italy's lowest low fertility. Demographic Research, 4(5), 133-162.

Dalla Zuanna, G., \& Micheli, G. A. (2004). Strong family and low fertility: a paradox?: New perspectives in interpreting contemporary family and reproductive behaviour. Kluwer Academic Publishers.

Davis, S. N., \& Greenstein, T. N. (2009). Gender ideology: Components, predictors, and consequences. Annual Review of Sociology, 35, 87-105.

De Ruijter, E., Treas, J. K., \& Cohen, P. N. (2005). Outsourcing the gender factory: Living arrangements and service expenditures on female and male tasks. Social Forces, 84(1), 305-322.

Engelhardt, H., Kögel, T., \& Prskawetz, A. (2004). Fertility and women's employment reconsidered: A macro-level time-series analysis for developed countries, 1960-2000. Population Studies, 58(1), 109-120.

Engelhardt, H., \& Prskawetz, A. (2004). On the changing correlation between fertility and female employment over space and time. European Journal of Population/Revue européenne de Démographie, 20(1), 35-62.

Fahlén, S., \& Olàh, L. (2018). Economic uncertainty and first- birth intentions in Europe. Demographic Research, 39(28), 795-834.

Friedman, D., Hechter, M., \& Kanazawa, S. (1994). A theory of the value of children. Demography, 31(3), 375-401. https://doi. org/10.2307/2061749.

Gavalas, V., Rontos, K., \& Salvati, L. (2014). Who becomes an unwed mother in Greece? Sociodemographic and geographical aspects of an emerging phenomenon. Population Space and Place, 20, 250-263.

Golaz, V., Lefèvre, C., \& Véron, J. (2018). La crise en Europe du Sud : vue d'ensemble. In V. Golaz, C. Lefèvre, \& J. Véron (Eds.), La crise dix ans après. Quels effets sur la conjoncture démographique des pays d'Europe du Sud ? (Vol. 239, pp. 7-20). Paris: Ined, Documents de travail.

Goldscheider, F., Bernhardt, E., \& Lappegård, T. (2015). The gender revolution: A framework for understanding changing family and demographic behavior. Population and Development Review, 41(2), 207-239.

Goldstein, J., Kreyenfeld, M., Jasilioniene, A., \& Örsal, D. D. K. (2013). Fertility reactions to the "Great Recession" in Europe: Recent evidence from order-specific data. Demographic Research, 29, 85-104.

Goldstein, J. R., Sobotka, T., \& Jasilioniene, A. (2009a). The end of lowest-low-fertility. Max Plank Institute for Demographic Research, Working Paper (pp. 2009-2029).

Goldstein, J. R., Sobotka, T., \& Jasilioniene, A. (2009b). The end of "lowest-low" fertility? Population and Development Review, 35(4), 663-699.

Gutiérrez-Domènech, M. (2008). The impact of the labour market on the timing of marriage and births in Spain. Journal of Population Economics, 21, 83-110.

Hakim, C. (2016). Key issues in women's work: Female diversity and the polarisation of women's employment. Routledge-Cavendish.

Hank, K. (2007). Proximity and contacts between older parents and their children: A European comparison. Journal of Marriage and Family, 69(1), 157-173.

Jalovaara, M., \& Miettinen, A. (2013). Does his paycheck also matter? The socioeconomic resources of co-residential partners and entry into parenthood in Finland. Demographic Research, 28(31), 881-916.

Joshi, H. (1998). The opportunity costs of childbearing: More than mother's business. Journal of Population Economics, 11, $161-183$. 
Karamessini, M. (2014). Structural crisis and adjustment in Greece: Social progression and the challenge to gender equality. In M. Karamessini \& J. Rubery (Eds.), Women and austerity: The economic crisis and the future for gender equality (pp. 165185). Routledge.

Kögel, T. (2004). Did the association between fertility and female employment within OECD countries really change its sign? Journal of Population Economics, 17(1), 45-65.

Kohler, H. P., Billari, F., \& Ortega, J. A. (2002). Low fertility in Europe: causes, implications and policy options. In F. R. Harris (Ed.), The Baby Bust: Who will do the Work? Who Will Pay the Taxes? (pp. 48-109). Lanham, MD: Rowman \& Littlefield Publishers.

Kotzamanis, B. (2018). La crise actuelle en Grèce et ses consequences sur la population. In V. Golaz, C. Lefèvre, \& J. Véron (Eds. ), La crise dix ans après. Quels effets sur la conjoncture démographique des pays d'Europe du Sud ? (Vol. 239, pp. 7-20). Paris: Ined, Documents de travail.

Kretsos, L. (2014). Youth policy in austerity Europe: the case of Greece. International Journal of Adolescence and Youth, 19(sup 1), 35-47.

Kreyenfeld, M. (2010). Uncertainties in female employment careers and the postponement of parenthood in Germany. European Sociological Review, 26(3), 351-366.

Kreyenfeld, M., Andersson, G., \& Paihlé, A. (2012). Economic uncertainty and family dynamics in Europe: Introduction. Demographic Research, 27(28), 835-852.

Lesthaeghe, R. (2010). The unfolding story of the second demographic transition. Population and Development Review, 36(2), 211-251.

Li, B., Lingsma, H. F., Steyerberg, E. W., \& Lesaffre, E. (2011). Logistic random effects regression models: a comparison of statistical packages for binary and ordinal outcomes. BMC Medical Research Methodology, 11, 77.

Liefbroer, A. C. (2005). The impact of perceived costs and rewards of childbearing on entry into parenthood: Evidence from a panel study. European Journal of Population/Revue Européenne de Démographie, 21(4), 367-391.

Lundberg, S., \& Pollak, R. A. (1996). Bargaining and distribution in marriage. Journal of economic perspectives, 10(4), 139-158.

Matsaganis, M. (2011). The welfare state and the crisis: the case of Greece. Journal of European Social Policy, 21(5), 501-512.

McDonald, P. (2000). Gender equity, social institutions and the future of fertility. Journal of Population Research, 17(1), 1-16.

McDonald, P. (2006). Low fertility and the state: The efficacy of policy. Population and Development Review, 32(3), 485-510.

Mills, M., \& Blossfeld, H. P. (2005). Globalisation, uncertainty and the early life course. A theoretical framework. In H.-. P. Blossfeld, E. Klijzing, M. Mills, \& K. Kurz (Eds.), Globalisation, Uncertainty and Youth in Society (pp. 1-24). London and New York: Routledge.

Mood, C. (2010). Logistic regression: Why we cannot do what we think we can do, and what we can do about it. European Sociological Review, 26(1), 67-82.

Neels, K., Theunynck, Z., \& Wood, J. (2013). Economic recession and first births in Europe: recession-induced postponement and recuperation of fertility in 14 European countries between 1970 and 2005. International Journal of Public Heath, 58(1), 43-55.

Nitsche, N., Matysiak, A., Van Bavel, J., \& Vignoli, D. (2018). Partners' educational pairings and fertility across Europe. Demography, 55(4), 1195-1232.

OECD Family Database. (2019). www.oecd.org/els/social/family/database.

Oppenheimer, V. K. (1988). A theory of marriage timing. American Journal of Sociology, 94(3), 563-591.

Oppenheimer, V. K. (1994). Women's rising employment and the future of the family in industrial societies. Population and Development Review, 293-342.

Paihlé, A., \& Solaz, A. (2012). The influence of employment uncertainty on childbearing in France: A tempo or a quantum effect? Demographic Research, 26(1), 1-40.

Pailhé, A. (2010). Effet attendu de la crise économique actuelle sur les naissances: quelques hypothèses. Politiques Sociales et Familiales, 100(1), 97-103.

Pailhé, A., \& Solaz, A. (2013). Employment instability and childbearing plans in a child-oriented country: Evidence from France. In Childbearing, Women's Employment and Work-Life Balance Policies in Contemporary Europe (pp. 65-96). London: Palgrave Macmillan.

Papadopoulos, T., \& Roumbakis, A. (2013). Familistic welfare capitalism in crisis: social reproduction and anti-social policy in Greece. Journal of International and Comparative Social Policy, 29(3), 204-224.

Rabe-Hesketh, S., \& Skrondal, A. (2008). Multilevel and longitudinal modeling using Stata. STATA Press books.

Rondinelli, C., Aasve, A., \& Billari, F. C. (2010). Women's wages and childbearing decisions: Evidence from Italy. Demographic Research, 22, 549-578.

Ruppanner, L. E. (2010). Cross-national reports of housework: An investigation of the gender empowerment measure. Social Science Research, 39(6), 963-975.

Salvati, L. (2018). Population growth and the economic crisis: understanding latent patterns of change in Greece, 2002-2016. Letters in Spatial and Resource Sciences https://doi.org/10.1007/s12076-018-0204-7.

Santarelli, E. (2011). Economic resources and first child in Italy: A focus on income and job stability. Demographic Research, 25(9), 311-336

Schneider, D., \& Hastings, O. P. (2017). Income inequality and household labor. Social Forces, 96(2), 481-506.

Skirbekk, V. (2008). Fertility trends by social status. Demographic Research, 18(5), 145-180.

Sobotka, T. (2011). Fertility in Central and Eastern Europe after 1989: Collapse and gradual recovery. Historical Social Research/ Historische Sozialforschung, 246-296.

Sobotka, T., Skirbekk, V., \& Philipov, D. (2011). Economic recession and fertility in the developed world. Population and Development Review, 37(2), 267-306.

Tragaki, A., \& Bagavos, C. (2014). Male fertility in Greece: Trends and differentials by education level and employment status. Demographic Research, 31(6), 137-160.

Trimarchi, A., \& Van Bavel, J. (2017). Pathways to marital and non-marital first birth: The role of his and her education. Vienna Yearbook of Population Research, 15, 143-179.

Tzanatos, Z., \& Monogios, Y. (2013). Public sector adjustment amidst structural adjustment in Greece: Subordinate, spasmodic and sporadic. In D. Vaughan-Whitehead (Ed.), Public Sector Shock The Impact of Policy Retrenchment in Europe (pp. 259299). Northampton: Edward Elgar Publishing Limited Edward Elgar Publishing Inc.. 
Van Bavel, J. (2012). The reversal of gender inequality in education, union formation and fertility in Europe. Vienna Yearbook of Population Research, 10, 127-154.

Vaughan-Whitehead, D. (2013). Public sector shock in Europe: Between structural reforms and quantitative adjustment. In D. Vaughan-Whitehead (Ed.), Public Sector Shock The Impact of Policy Retrenchment in Europe (pp. 1-42). Northampton: Edward Elgar Publishing Limited Edward Elgar Publishing Inc..

Vignoli, D., Drefahl, S., \& De Santis, G. (2012). Whose job instability affects the likelihood of becoming a parent in Italy? A tale of two partners. Demographic Research, 26, 41-62.

Vignoli, D., Tocchioni, V., \& Salvini, S. (2016). Uncertain lives: Insights into the role of job precariousness in union formation in Italy. Demographic Research, 35, 253-282.

Vrachnis, N., Vlachadis, N., Iliodromiti, Z., Vlachadi, M., \& Creatsas, G. (2014). Greece's birth rates and the economic crisis. The Lancet, 383(9918), 692-693.

\section{Publisher's Note}

Springer Nature remains neutral with regard to jurisdictional claims in published maps and institutional affiliations.

Submit your manuscript to a SpringerOpen ${ }^{\odot}$ journal and benefit from:

- Convenient online submission

- Rigorous peer review

- Open access: articles freely available online

- High visibility within the field

- Retaining the copyright to your article 